Eline Waerp

\title{
Humanitarian Borderwork? An Analysis of Frontex's Discourses and Practices
}

MIM Working Paper Series 19: 3

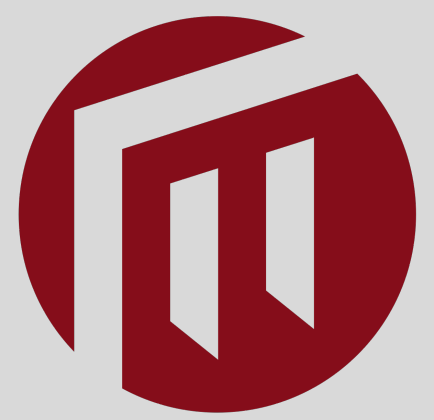




\section{MIM Working Paper Series No 19: 3}

Published

2019

Editor

Anders Hellström, anders.hellstrom@mau.se

Published by

Malmö Institute for Studies of Migration, Diversity and Welfare (MIM)

Malmö University

20506 Malmö

Sweden

ISBN 978-91-7877-057-1

DOI 10.24834/9789178770540

Online publication

www.bit.mah.se/muep 


\section{ELINE WAERP}

\section{Humanitarian Borderwork? An Analysis of Frontex's Discourses and Practices}

\section{ABSTRACT}

The concept of 'humanitarian borderwork' (Pallister-Wilkins 2017) entered the social sciences the last couple of years, in the wake of the 2015 migration crisis to the EU. With roots in the 'humanitarian border enforcement' discourse (Williams 2016) that developed in the US post-9/11, the concept suggests that the goals of 'migrant safety' (i.e. human security) and 'border control' (i.e. state security) are mutually attainable. This 'humanitarian-security' (Andersson 2017, De Lauri 2018) or 'safety/security' (Williams 2016) nexus casts increased border control as not the cause of, but the remedy to, migrants' vulnerability and death. 'Humanitarian borderwork' further implies a convergence between two seemingly distinct concepts: 'humanitarianism' and 'borderwork' (Walters 2011). Whereas 'humanitarianism' has traditionally been associated with a concern for humanity, human rights, alleviation of suffering, and the principle of 'do no harm'; 'borderwork' has been preoccupied with exclusion, control, security and monitoring/surveillance (Pallister-Wilkins 2015b). And whereas humanitarian action has traditionally been carried out by depoliticized, independent actors (notably NGOs) with the sole purpose of providing humanitarian assistance (Redfield and Bornstein 2011); humanitarianism is now increasingly being delivered by (supranational) state-actors, such as the EU's Border and Coast Guard Agency (Frontex) - which claims to be just as preoccupied with saving lives as protecting the EU's external borders.

This begs the questions: are 'humanitarianism' and 'borderwork' compatible concepts? And if so, in the case of the EU, how humanitarian is Frontex's borderwork? Informed by a literature review of the genealogy of the concepts of 'humanitarianism' and 'humanitarian borderwork', the paper problematizes the latter and seeks to answer those questions by analyzing and comparing Frontex's humanitarian discourses and practices to the understanding of humanitarianism within anthropology - a field that has studied it extensively. The paper thus provides part of the literature review and theoretical- and conceptual framework for the dissertation, to be complemented with more empirics at a later stage. Arguing that while Frontex's 'humanitarian borderwork' fails to meet the criteria in the traditional understanding of humanitarianism, it does 
succeed in situating itself within the 'new humanitarianism' (Nascimento 2015) that emerged after the end of the Cold War - where state actors play a larger role, and militarization and securitization of borders increasingly shape humanitarian action.

\section{KEYWORDS}

Humanitarian borderwork, Frontex, discourses and practices, new humanitarianism.

\section{BIOGRAPHICAL NOTES}

Eline Wærp is a PhD student in International Migration and Ethnic Relations (IMER) at the Department of Global Political Studies, Malmö University. She is interested in the various discourses and practices shaping European border management, especially elements of security, crisis and humanitarianism.

\section{CONTACT}

eline.waerp@mau.se 


\section{INTRODUCTION}

Given practical and strategical overlap in goals and operations on the ground, militarism and humanitarianism have become inextricably linked (Gilman 2012 in De Lauri 2018:4, emphasis added).

Understanding contemporary regimes of border governance necessitates attending to the entangled relationship between militarization, securitization and humanitarianism (Williams 2016:27, emphasis added).

Between 2014-2017, an estimated number of 14,445 migrant deaths were reported in the Mediterranean Sea by the International Organization for Migration (IOM 2018a). 2016 was a record high year, with more than 5000 reported 'dead' or 'missing' (IOM 2018 b). In 2015, more than a million crossed the Mediterranean, according to the United Nations High Commissioner for Refugees (UNHCR 2016). Most irregular migration to Europe takes place via the sea route - with 363,577 sea arrivals compared to 26,875 land arrivals in 2016 - arriving at the southern fringes of Europe: Spain, Italy, Malta or Greece (IOM 2018b). Not everyone makes it, however, as news stories of crammed boats capsizing or going missing have illustrated. UNHCR (2016) statistics estimated the likelihood of dying while crossing to Europe as 1 in 88 in 2016, and as high as 1 in 47 crossing between Libya and Italy (the Central Mediterranean route). These are most often vulnerable people who have fled from instability and insecurity in their home countries, whose future is in the hands of the EU's ever more restrictive border regime. Presumably, with greater SAR capacity at sea or the opening of legal pathways to the EU, these deaths are lives that could have been saved. This notwithstanding, this tragic situation has largely been framed as a 'security crisis' by the EU - a 'threat' to the integrity of the Union's external borders and the safety of EU citizens, which has to be combated (Jeandesboz and Pallister-Wilkins 2014, 2016). In contrast to the relief provided to migrants by the NGOs operating in the Mediterranean, the actor deemed most appropriate to deal with the 'crisis' in the eyes of the EU was Frontex - the European Border and Coast Guard Agency. In the last decade, however, Frontex has started to frame its border control operations in a more 'humanitarian' manner (Campesi 2014, Aas and Gundhus 2015), with concerns such as the protection of fundamental rights and SAR operations included in its revised mandate - with the latter becoming almost 'everyday practice' according to some scholars (see Pallister-Wilkins 2015, 2017). Pallister-Wilkins (2017) notes how EU border control practices have changed over the last decade, with an increased focus on saving lives. This escalated use of humanitarianism in both discourse and practice within EU border control has, however, coincided with a critique of lack of humanitarian responses, the decrease of safe and legal routes into the EU, along with the recent EU deals with Libya and Turkey, which are aimed at preventing migrants from entering the EU through these countries. There is 
thus an apparent paradox in how Frontex frames itself: on the one hand, as the EU's 'border watchdog', preoccupied with monitoring, surveilling, policing, and controlling the external borders; and on the other hand, as a humanitarian actor, rescuing migrants from 'the bad guys' (i.e. smugglers), overfilled boats, and dangerous situations.

These complexities and paradoxes in Frontex's portrayal of itself and its role in the management of the EU's external borders brings us to the puzzle of this paper: is there such a thing as 'humanitarian borderwork'? If so, what might it look like? And how compatible are the concepts of 'borderwork' and 'humanitarianism'? More specifically, this paper aims to investigate the following: How does humanitarianism feature in Frontex's discourse and practices, and how does it stand compared to the traditional notion of humanitarianism? How humanitarian is Frontex's borderwork? In order to answer these questions, the following steps will be taken: a genealogy of the concept of humanitarianism - how it has come to be understood, defined and operationalized in a field that has studied it extensively, anthropology (see Redfield 2005, Ticktin 2014, Fassin 2012); an overview and analysis of how the concept of 'humanitarian borderwork' has been understood in critical border studies, along with preliminary analysis of how Frontex draws on humanitarian discourses and practices, mostly drawing on secondary sources.

\section{BACKGROUND}

Frontex was originally established by Council Regulation (EC) 2007/2004 in 2004 as the European Agency for the Management of Operational Cooperation at the External Borders of the Member States of the EU, with the main task to protect the EU's external borders (Frontex 2018a). The original mandate was expanded in Regulation (EU) 2016/1624, according to President of the European Council, Donald Tusk, in order to 'regain control of the EU's external borders' and 'save Schengen' (European Council 2016). Frontex is one out of the many new quasi-democratic EU agencies established within the area of freedom, security and justice (AFSJ) the last two decades; and has been subject to both academic and public scrutiny (Ekelund 2014, Aas and Gundhus 2014). In addition to questions regarding its legality and legitimacy, which seems to plague the EU (see Eriksen 2011, Vauchez 2016), Frontex has repeatedly been accused by human rights organizations and the UNHCR for facilitating the detention of migrants in poor detention centers, breaching the non-refoulement principle through its push-back operations - effectively denying migrants the right to apply for asylum as provided by the 1951 Geneva Convention on Refugees (Leonard 2009, Dünnwald 2011) - and contributing to making the external borders of the EU a 'site of suffering and death' of tens of thousands of people (Jeandesboz and Pallister-Wilkins 2016:318).

In 2011 a Human Rights Watch report entitled 'The EU's Dirty Hands' criticized Frontex for helping the Greek authorities arrest 12,000 migrants and detain them in overcrowded detention centers which did not meet minimum human rights standards, 
and where the migrants were subject to inhumane and degrading treatment (HRW 2011). Frontex provided Greek authorities with manpower and material support to facilitate the detention, despite the European Court of Human Rights (ECHR) and the Court of Justice of the European Union (CJEU) ruling that Greek detention centers at the time subjected migrants to maltreatment (ibid., Trauner 2016). In response to the report, Frontex emphasized its respect for fundamental rights, but at the same time reiterated that the agency is not responsible for 'detention on the territory of the Member State', and that it had 'been expected to operate in an exceptional environment' (Frontex 2011). So while Médecines Sans Frontières (MSF), the Red Cross and other NGOs were providing emergency relief to migrants, Frontex - representing the EU member states' coordinated response to the migration 'crisis' - was handing migrants over to the Greek authorities' inhumane detention centers.

\section{THEORY AND METHODS}

The paper draws on anthropology, critical border studies, migration studies, and critical security studies. Informed by a constructivist epistemology, the paper emphasizes the social constructedness of concepts and phenomena. This constructivist approach allows for the analysis of processes of discursive construction and examination of different actors' framings, understandings, and invocations of various concepts and phenomena (Jørgensen and Phillips 2002). The paper draws inspiration from critical theory and critical discourse analysis in its theoretical framework and a methodological approach, enabling an interrogation of Frontex's invocation of humanitarianism in its official discourses and practices and an examination of how this overlaps or contrasts with the traditional concept of humanitarianism in anthropology.

More concretely, an overview of some of the key literature on humanitarianism within anthropology (see Redfield 2005, Ticktin 2014, Fassin 2012) is provided in order to narrow down this elusive concept, and how it has evolved over the past few decades. Similarly, a review of existing scholarship within critical border studies on the 'humanitarian border' (Walters 2011) and 'humanitarian borderwork' (Cuttitta 2014, Pallister-Wilkins 2015b, Williams 2016) will also be provided. The paper thus draws primarily on existing literature in order to lay the conceptual- and theoretical groundwork of the dissertation, to be complemented with more empirical material at a later stage. Accordingly, the paper takes more the form of a theoretical- and conceptual discussion, rather than a strict empirical analysis of a clearly demarcated material. Lastly, the paper aims at expanding discourse analysis' toolbox by utilizing Jensen's (2016) concept of 'discourse co-optation' (which draws on Fairclough's concept of interdiscursivity) in analyzing how the $\mathrm{EU}$ and Frontex have incorporated the humanitarian critique articulated by human rights organizations into their own official discourses, depriving them of their main critique (that 'Frontex kills'), thus strengthening Frontex's position as a 'humanitarian actor' that rather saves lives. 


\section{LITERATURE REVIEW AND DISCUSSION}

Humanitarianism throughout Time: From Humanity, Impartiality, Neutrality and Independence, to Politicization, Securitization and Militarization?

\section{Classical Humanitarianism}

So what do we already know about humanitarianism, and what the concept entails? And how does that reconcile, or not, with 'humanitarian borderwork'? In order to answer these questions, a brief genealogy and overview of how the concept of humanitarianism has evolved and been defined in the literature will be provided as a backdrop for the subsequent analysis.

What is humanitarianism? There seems to be no one-agreed upon, universal definition of humanitarianism. As Redfield and Bornstein (2011) emphasize in their 'Introduction to the Anthropology of Humanitarianism', the concept remains contested, with its definition varying according to the respective discipline in which it is deployed. They note that within development studies, humanitarianism is often conceptualized as 'aid' or 'charity', with a focus on 'the act of giving' as a way or an economic means to confront poverty or underdevelopment. The development discourse is thus inherently and resolutely progressive; conditions should improve...' so as to ensure 'human good in an imagined future' (Redfield and Bornstein 2011:5-6). Within the human rights discourse, on the other hand, humanitarianism is conceived of in a more legalistic or philosophical fashion, where 'justice defines well-being'. The human rights discourse is hence more focused on specific cases where political liberties have been violated or 'wrongs' have been made, with the UN's Universal Declaration of Human Rights (1948) as a landmark (ibid.).

Humanitarianism in the more 'classical' or 'traditional' sense, however, include a focus on the bodily/physical or 'psychological' condition of suffering, with the well-being and health of people as its ultimate goal (Redfield and Bornstein 2011). This more 'medical humanitarianism' has also been conceptualized as 'emergency humanitarianism', referring to the tendency of humanitarian actors, such as NGOs, to largely (or only) respond to or provide relief in times of 'crisis' (Barnett 2011 in Skinner and Lester 2012), accompanied by the 'salvational narratives of rescue' (Redfield and Bornstein 2011:12). According to Barnett (2011), this is the prevailing form of humanitarianism today. Others, however, argue that today's humanitarianism is rather characterized by being politicized and even militarized (De Lauri 2016, 2018) - which we will return to later. Moreover, humanitarianism can be driven by either religious faith, with spiritual focus on the care of the soul, or a more secular concern for human empathy (Redfield and Bornstein 2011).

Evidently, humanitarianism can be motivated by a variety of sentiments, be it moral, medical, religious, secular or even political or military ones. As Redfield and 
Bornstein (2011:17) underscore: 'Humanitarianism...is several things at once: a structure of feeling, a cluster of moral principles, a basis for ethical claims and political strategies, and a call for action'. What the different 'strands' of humanitarianism all have in common, however, is the view that 'suffering is a preventable tragedy' (Redfield and Bornstein 2011:16) and an overarching goal of 'ameliorating or improving aspects of the human condition' (ibid.:5). In the words of a former executive director of MSF-USA: 'humanitarian action's single-minded purpose (is) alleviating suffering, unconditionally and without any ulterior motive' (de Torrente 2004 in Ticktin 2014:276, emphasis added). Thus, humanitarianism 'defines itself around the collective figure of the human, measured through basic needs and dignity' (Redfield and Bornstein 2011:17-18).

Despite these different understandings of humanitarianism, there are some key, founding principles that are widely recognized in both the literature and the field, that go back in time. These are, namely: humanity, impartiality, neutrality, independence (ibid.), universality, transparency and accountability (MSF 2018, ICRC 2018), along with the language of 'do no harm' (Sandvik 2017) or the related principle of 'do more good than harm' (Williams 2016), and the belief that 'all lives are equal' (Guilhot 2012). These 'guiding principles' are meant to ensure the 'equal treatment of all individuals with sole regard to their immediate needs' (Nascimento 2015:n.p.), regardless of their political, religious or ethnic affiliations. In other words, humanitarian actors should not take sides in conflicts or discriminate with regards to who to help. These principles are found in the mission statements of most of the major humanitarian organizations today (e.g. MSF 2018, ICRC 2018, NRC 2018, Save the Children 2018), but seem to have weakened over time, however, as we will come to shortly.

In contrast to the elusive or multifaceted definition of humanitarianism, there is a wider consensus regarding the origins of the concept. The traditional form of humanitarianism is commonly traced back to the founding of the Red Cross in the 1850s by Henry Dunant, in response to the treatment of wounded in war (Redfield and Bornstein 2011, Skinner and Lester 2012) - although some go as far back as to the antislavery movement in the 1700s, and efforts of European administrators and missionaries to care for its colonial populations, among others (ibid.). Nevertheless, there is a growing awareness within anthropology and other disciplines that the concept of humanitarianism is changing, shifting away from the traditional understanding of humanitarianism as neutral, impartial, depoliticized and categorically against militarized forms of violence, into a fragmented, hybrid form - a so-called 'new humanitarianism', where the mentality seems to be 'anything goes' (Nascimento 2015, De Lauri 2018).

\section{New Humanitarianism}

This 'new humanitarianism' emerged in the 1990s, in response to the more complex humanitarian emergencies of the post-Cold war era - characterized by more violent conflicts, more internal conflicts, and an increasingly blurred distinction between 
combatants and civilians (Nascimento 2015). As the traditional or 'old' humanitarianism increasingly became accused of failing to adequately respond to humanitarian emergencies around the world due to its narrow, short-term scope of alleviating immediate suffering, refusal to take sides in conflict, and denunciation of violent intervention - 'new humanitarianism' gained ground. Promising more resolute and effective action - enabled through discarding the traditional principles - along with the broader and more long-term goals of ensuring 'peace and stability' (Nascimento 2015), this 'revised' version of humanitarianism claimed to be better equipped to respond to the challenges of this new era. The new 'intricate humanitarian crises' - exemplified by the genocide in Rwanda and the Balkans war - thus rendered 'traditional responses based on the classical principles of impartiality and neutrality...no longer effective or sufficient to respond to such complex needs' (Nascimento 2015:n.p.).

So what characterizes this 'new humanitarianism'? In addition to a move away from the traditional principles, this 'new form' of humanitarianism incorporates a broader scope and longer-term objectives than before, such as development, peace (Nascimento 2015), stability, the promise of 'normality' (Billaud and De Lauri 2016) and importantly security (Williams 2016). These longer-term goals hence violate the traditional principles, as they involve political/state actors operating according to their own agenda (as in the case of the US army fighting to 'free the Afghan people from the Taliban'), sometimes encouraging taking sides in conflicts or utilizing violence as a means to achieve their objectives. This has been witnessed by the more frequent 'misuse' of humanitarian interventions, especially with the prominence of security concerns after 9/11 (Nascimento 2015) - with the invasions of Iraq and Afghanistan in the early 2000s and the UN-sanctioned NATO bombings of Libya in 2011 (all under 'humanitarian pretenses'), being oft-cited cases (Billaud and De Lauri 2016, De Lauri 2018). As a consequence of the fragmented and increased complexity of humanitarianism, along with its widening field and scope of application, more actors have entered the field, 'proudly proclaiming' to be humanitarian practitioners (Nascimento 2015). This in turn has led to a politicization and subsequent militarization of humanitarianism, as state actors (often the military) and NGOs operate side by side in this 'new field' of humanitarianism.

What are some consequences of this more recent evolution or 'morphing' of humanitarianism? One consequence, according to Apthorpe (2014), is the emergence of a distinction between 'assistance' and 'protection' practitioners: with the former preoccupied with the more traditional humanitarianism in the form of emergency relief, and the latter concerned with the wider cause of 'universal human rights norms' that need to be protected. The issue with 'protection' practitioners, according to Apthorpe (2014:359), is not their preoccupation with human rights, but rather their propensity to not see anything 'un-humanitarian' about mixing (and sometimes confusing) militarism with humanitarianism - which goes against the very ethos of humanitarianism and has proven weak to political manipulation. This conflation of militarism and 
humanitarianism has further been institutionalized by the UN in the controversial 'Responsibility to Protect' (R2P) doctrine - first used in Libya in 2011 - which has been accused of condoning military intervention in the name of humanitarianism. This conceptual blurring has been referred to by scholars as 'armed love' (Ticktin 2011), 'humanitarian militarism', 'compassionate militarism', 'humanitarian war', or even 'humanitarian terrorism' (De Lauri 2018). Capturing the inherent contradictions of this merging, De Lauri (2018:3) highlights 'humanitarian militarism's capability to offer, at the same time, violence and promise, cruelty and caregiving'.

A related consequence of the politicization of humanitarianism is the risk of political hijacking of the concept. Scholars have noted the increasing use of humanitarianism as a means to reach a political objective, a convenient 'cloak' providing legitimacy to armed interventions, or its misuse as a tool of governance used to pursue a state's security agenda, to the detriment of the supposed beneficiaries (Nascimento 2015, De Lauri 2018). Nascimento (2015:n.p.) argues that "humanitarian rhetoric" has become another instrument of foreign policy at the service of states', and that it serves as a new control mechanism to solve non-humanitarian (largely political) problems. Ticktin (2014:281) further notes how 'humanitarianism' is emerging as a new form of government, 'as [an] international order, as a regime of care and also violence, and as exclusion as much as inclusion', tapping into the complexities of the concept of 'humanitarian governance', where these dualities have always co-existed.

Lastly, in analyzing a situation they characterize as 'the humanitarian theatre' of Afghanistan after the 2001 invasion, Billaud and De Lauri (2016:58) use the notion of 'carnivalesque' to highlight the '...deceptive potential of humanitarianism and its capacity to produce and shape social imaginaries with great persuasive power', referring to the US narrative that the invasion would bring 'democracy and hope' to Afghans. They further argue that the false 'narrative of normality' promised by humanitarian interventions instead produce the experience of immobility, confinement and entrapment for the local population. Problematizing the instrumentalization of humanitarianism, De Lauri (2016) argues that humanitarianism has shifted from being a 'powerful discourse to a form of power' (Donini 2010 in De Lauri 2016:3), becoming a 'political mode of controlling territories and lives' - with the ideals of humanitarianism becoming further detached from what actually happens on the ground. Contrary to the mainstream anthropological account of how humanitarianism developed as the antithesis to violence, but later became corrupted by it, Skinner and Lester (2012) and De Lauri (2016:3) argue that the two emerged in association with each other: from the '...civilizing goals of Christian missions and colonial projects... [to] the hegemonic diffusion of the democratic nation-state model, and the US's attempts to establish itself as world leader'. So where does this leave us? 


\section{Humanitarian Borderwork?}

Now that we have examined what humanitarianism is (or is not) according to the literature, it is time to interrogate what 'humanitarian borderwork' is, or purports to be, according to the critical border studies literature; and how humanitarian it actually is i.e., how well it fits within the different 'paradigms' illustrated above. Are 'humanitarianism' and 'borderwork' compatible concepts, or are they in 'natural opposition' to each other? Before we embark on this, however, a brief consideration of the 'humanitarian border' (Walters 2011) - the space where the supposed 'humanitarian borderwork' takes place - is necessary.

\section{The 'Humanitarian Border'}

What is the 'humanitarian border', and where do we find it? Similarly to the concept 'humanitarian borderwork', the 'humanitarian border' appears counterintuitive since the same tension between the two concepts is existent here too, but also as Walters (2011:139) points out, since humanitarianism is thought to 'have no boundaries' or 'transcend all borders' (as e.g. MSF's name and vision adheres to). The concept of humanitarianism is also here fraught with ambiguity, and Walters (2011), who has written on the 'birth of the humanitarian border', emphasizes the necessity of understanding contemporary humanitarianism as 'a site of ambivalence and undecidability' (ibid.:144). He sees 'the humanitarian' as a 'complex domain possessing specific forms of governmental reason', concerned with doing 'the bare minimum' (e.g. simply recording migrant deaths) - or what Redfield (2005) terms 'minimalist biopolitics' (in terms of MSF's 'medical humanitarianism') (Walters 2011:143).

According to Walters (2011:139/145, emphases added), the 'humanitarian border' can be conceived of as 'a situation where the actual borders of states and gateways to the territory themselves become 'zones of humanitarian government', 'holding together in an uneasy alliance a politics of alienation with a politics of care, and a tactic of abjection and one of reception'. So where are these borders to be found? 'Humanitarian borders' are not universal phenomena, but rather appear in certain areas under specific circumstances, most notably on the borders between the Global North and the Global South, 'where gradients of wealth and poverty, citizenship and non-citizenship appear especially sharply' (Walters 2011:146). In other words, the 'humanitarian border' is not fixed geographically, but is dynamic and fluctuates in time and space according to migratory routes and violent border practices (ibid.).

Walters (2011:138, emphasis added) traces the emergence of the 'humanitarian border', which he argues emerged as a means to govern or 'compensate' for the increasingly violent migration control regime, to a point in time 'once it becomes established that border crossing has become, for thousands of migrants seeking...to access the territories of the global North, a matter of life and death'. Similarly, Squire (2017:514), writing about the 'biophysical violence' of borders, discusses what she terms 
'the emergence of death as routine or normalized dimension of contemporary bordering practices'. Thus, Walters $(2011: 147)$ understands the 'humanitarian border' as the 'effect of a particular governmental strategy', where humanitarianism operates on certain border spaces due to the securitization and militarization of borders. As he states:

...if border crossing has become a matter of life and death, this is because we have situation where military tactics, advanced surveillance technology, naval patrols, armed guards and guard dogs, watchtowers, razor wire ... are all deemed politically necessary and legitimate elements in the "defense" of the borders of the Global North faced with an "invasion" of migrants... (Walters 2011:147, emphasis added).

Indeed, Cuttitta (2014:36) argues that 'the humanitarian border is but a fig leaf for covering up exclusionary policies aimed at denying opportunities for asylum and protection in Europe'. Walters (2011:155) also notes that politics is key to the study of the 'humanitarian border', as it is both 'generative and immanent to it', and serves to define the boundaries of 'the humanitarian' through political struggles. Humanitarianism thus should not be seen as a neutral or depoliticized field, but rather as 'an emergent zone of politics in its own right' (ibid.:157, emphasis added).

\section{From 'Protecting Borders' to 'Saving Lives'?}

If humanitarianism and the 'humanitarian border' are ambiguous concepts, 'humanitarian borderwork' is equally so. Literature on the topic has expanded rapidly the last few years (see Cuttita 2014, Williams 2016, Pallister-Wilkins 2017, Andersson 2018), with much anthropological literature concentrating on the wider theme of 'humanitarian governance' (e.g. Feldman and Ticktin 2010, Agier 2011, Fassin 2012). Similar to 'humanitarian militarism', the term implies a mixing of two intuitively contradictory concepts: 'humanitarianism' and 'borderwork'. 'Borderwork' is here used to refer to the work/practices that takes place at the borders, including patrolling, protecting, securing, monitoring, surveilling and defending the border (see PallisterWilkins 2017). Whereas humanitarianism involves a plea for humanity, non-violence, human rights and universality; 'borderwork' is by nature hierarchical, exclusionary and violent, underpinned by the principles of state sovereignty and territorial integrity (ibid.). However, these seemingly disparate concepts seem to have converged in recent years, as witnessed by the increasing use of a humanitarian discourse by border control agencies in Europe (Pallister-Wilkins 2015b, 2017), the US (Williams 2016), and Australia (Little and Vaughan-Williams 2017). To illustrate, when the Italian government launched Operation Mare Nostrum in response to the deaths of over 400 migrants off the coast of Lampedusa in the fall of 2013, the Italian Defense Minister referred to it as both a 'humanitarian operation' to save lives and a 'security operation' (ibid.:35). 
As Cuttitta (2014:21) illustrates, whereas European border controls in the past were framed largely in security terms, after turn of the century 'humanitarian concerns have progressed towards centre stage', becoming an 'emergent transnational norm' (Little and Vaughan-Williams 2017:541). De Lauri (2018:10-11, emphasis added) captures this development in the humanitarian-security nexus (see also Andersson 2017), highlighting that 'a key issue is the convergence between practices of humanitarian rescue and processes of sovereign capture more traditionally associated with border policing...with the consequent convergence of state agents and humanitarian workers'. He emphasizes that what are now supposedly 'humanitarian borders', 'reflect the political and legal shift whereby policing operations become articulations of politics of compassion and repatriation' (De Lauri 2018:11).

Williams (2016:27, emphasis added) further notes that 'understanding contemporary regimes of border governance necessitates attending to the entangled relationship between militarization, securitization and humanitarianism' (see also Andersson 2017, Little and Vaughan-Williams 2017). She develops what she terms the safety/security nexus to 'draw attention to the way in which migrant safety and border security are seemingly reconciled in both official state discourse and policy', with migrant safety and border security being framed as mutually attainable goals (i.e. greater border security is framed as the means to increase migrant safety, rather than decreasing it) (Williams 2016:27). Fassin (2007) terms this the 'militaro-humanitarian moment', where war and humanitarian action, 'typically presumed to be forces opposed to one another, enter into a tense but mutually supportive relationship' (Fassin 2007 cited in Walters 2011:154).

\section{The US Context: 'Humanitarian Border Enforcement'}

But when did 'borderwork' become linked with humanitarianism? In order to analyze this development in the EU, it can be useful to look across the Atlantic, where 'humanitarian borderwork' seems to have longer roots. Williams (2016:31) traces this coupling back to the early 2000s, when the US Border Patrol - in response to mounting criticism from human rights NGOs of the increasing militarization and securitization of its southern border after 9/11 - started emphasizing the dual role of border officials: protecting the border and at the same time saving lives. In the words of a US Customs and Border Protection (CBP) commissioner: 'A secure border is a safe border, and a safe border saves lives' (Kane 2004 in Williams 2016:31, emphasis added). According to Williams (2016:31), this shift in the discourse and framing of 'borderwork' is further marked by a move by the CBP away from 'dismissing' migrant deaths to actively recording numbers of rescues and deaths (alongside numbers of apprehensions and amounts of narcotics seized) in their official statistics. She notes how the number of border officials trained in rescue and emergency medical procedures have also entered the annual reports, along with the inclusion of images of border officials both providing 
medical care to migrants and rappelling from helicopters in official promotions and recruitment videos (ibid.).

What are some of the implications of this 'humanitarianization of border enforcement', as Williams (2016) terms it, is it not a positive development? This could have been the case, had it actually been humanitarian. As Williams (2016) illustrates, the humanitarian aspect of border enforcement in the US is hardly genuinely humanitarian. For instance, she notes that the number of border officials with adequate medical training remains low (despite CBP claims), and far from being 'non-discriminatory' or 'universal', medical help is contingent on apprehension. Moreover, she highlights how the linking of border security and migrant safety has been used by the CBP to justify the further criminalization of unauthorized migration in order to deter future migration and subsequent deaths (Williams 2016:32). This leads Williams (2016:32, emphasis added) to conclude that 'criminalisation is rendered simultaneously punitive and humanitarian', and that 'in reframing arrests as rescues, [border] enforcement becomes humanitarian intervention that is in the best interest of migrants' (ibid.:33, emphasis added). This humanitarian discourse is being sustained by the CBP, despite the fact that, as she points out, migrant mortality rates have actually increased since the early 2000s (2016:32).

Lastly, Williams (2016:33) notes how the US Border Patrol has taken steps to criminalize the activities of NGOs operating at the border (e.g. by removing water put out along migrant trails in the desert, raiding camps and threatening with arrest), preventing them from providing medical care and aid to migrants - thus leaving the US Border Patrol monopoly on humanitarian assistance on the US-Mexico border. As she points out, smugglers - not global inequalities, conflicts or deadly borders - are blamed for migrant deaths, hence justifying the criminalization of perceived smuggling activities of NGOs (Williams 2016) and rejecting any responsibility on part of the state (see Squire 2017). As a result of this, she claims that '...humanitarianism sustains and enables the continued militarization of the border by providing a militarised 'solution' to the violence that results from ever more intense border militarization efforts' (Williams 2016:33, emphasis added) - all to the detriment of migrants (see Squire 2017 for a USEU comparison of practices of 'governing migration through death').

\section{The EU Context: From 'Frontex Kills' to 'Frontex Saves Lives'?}

How has 'humanitarian borderwork' developed in Europe, and more specifically within the context of the EU's border and coast guard agency, Frontex? Pallister-Wilkins (2017:85), among others (e.g. Aas and Gundhus 2014, Andersson 2017, Perkowski 2018), traces a shift in borderwork in Europe over the last decade, when an increased focus on incorporating more 'humanitarian elements' (such as the inclusion of a SAR mandate to Frontex in 2016) into already existing border practices emerged. Noting that 'moral sentiments and humanitarian concerns now frame Frontex's discourse and action' (Pallister-Wilkins 2015b:60), she attributes this sudden emphasis on humanitarianism in 
borderwork to the closing down of safe and legal routes into the EU (by the EU itself), which created violent border spaces in need of humanitarian interventions (see also Walters 2011, Williams 2016). The resulting 'humanitarian borderwork' that we see today is thus a product of the fortification of the EU and mounting death tolls at its external borders, and a 'solution' to a problem created by the Union itself.

Moreover, this increased willingness to help on Frontex's part has been aided by recent technological developments (Pallister-Wilkins 2015b), which has made it easier to spot migrants at risk through the use of drones and thermal vision cameras transforming the 'humanitarian border' into a 'biometric border' (see Amoore 2016), and making Frontex's SAR operations resemble military operations (Little and VaughanWilliams 2017). The productive or performative power of humanitarianism should thus not be underestimated, as humanitarianism 'frames and legitimises interventions at sea ... promotes certain technologies and shapes the operational responses of the border police' (Pallister-Wilkins 2015b:59). As Walters (2011:154, emphasis added) underscores: 'humanitarianism, insofar as it operates as a source of governmental innovation, has made the policing of borders a much more complex, polymorphous and heterogeneous affair'.

So how does Frontex employ humanitarianism in its discourse and practices? Following the 2011 amendment to Frontex's regulation, a Fundamental Rights Officer, tasked with ensuring that fundamental rights are observed; and a Consultative Forum, providing advice on fundamental rights matters, were inserted into Frontex's structure (Frontex 2018c). This was later on followed by a Complaint Mechanism in 2016, providing any person whose fundamental rights have been violated by a Frontex activity the possibility to lodge a complaint against the agency (Frontex 2018d). According to the 'Fundamental Rights at Frontex' section on its official website, Frontex 'considers respect for and the protection of fundamental rights to be an unconditional and essential component of effective integrated border management', and 'strictly adheres to the Charter of Fundamental Rights of the European Union, the European Convention for the Protection of Human Rights and Fundamental Freedoms, as well as relevant international law' (Frontex 2018c, emphases added). In addition, all Frontex staff and other participants in Frontex operations receive training on fundamental rights and 'access to international protection' (ibid.).

These are all improvements compared to the original 2004 Frontex regulation, where any references to humanitarian mechanisms or practices were lacking (Pallister-Wilkins 2015b). Pallister-Wilkins (2015b:64) notes, however, how Frontex officials tend to invoke a 'victim and savior dichotomy' through reproducing the narratives of 'the bad smuggler' and 'the helpless migrant' who is abandoned in precarious situations - only to be saved by Frontex patrols. The humanitarian discourse here works to gloss over the role played by the EU's restrictive border regime in enticing both irregular migration and smuggling (Andersson 2017), and legitimizes military action that would otherwise have been deemed unacceptable (Little and Vaughan-Williams 2017). 
Now that we have looked at some examples of how Frontex's humanitarian discourse is manifested, it's time to examine what the agency's 'humanitarian borderwork' looks like in practice. Pallister-Wilkins $(2015 \mathrm{~b})$ takes the case of Evros, where the borderspace between Greece and Turkey developed into a 'humanitarian border' with the construction of a large fence on an open field migrants used to cross over, pushing them instead into crossing the fast-flowing river. This more dangerous route resulted in migrants being stranded in the middle of the river after the boats provided to them by the smugglers broke down, transforming Frontex's more traditional border patrols into life-saving missions. The 'limitedness' of this form of humanitarianism (as traditional humanitarianism has been criticized for), however, is evident. As Pallister-Wilkins (2015b) notes, after rescuing the migrants, Frontex has done its 'job' and fulfilled its humanitarian duty, and need not be concerned for what happens to the migrants next. This form of 'limited humanitarianism' is also evident in another example she provides from Evros, where a group of migrants hiding in the field close to the border were discovered by a Frontex border patrol. Not being able to do much more than throwing them some blankets and water, the border patrol simply waited until the migrants eventually tried to cross the border and could be arrested and sent to a detention center (Pallister-Wilkins 2015b).

Another oft-cited example of 'humanitarian borderwork' are search and rescue operations (see e.g. Andersson 2017), which are according to Pallister-Wilkins (2017:91), 'the most prominent forms of humanitarian borderwork'. Saving lives and reducing the risk of border crossings seems to fit within 'emergency humanitarianism' or the more traditional 'medical humanitarianism', which both seek to alleviate immediate suffering. On the other hand, other objectives seem to be at play here too. Whereas border policing traditionally has been limited to territorial waters, adopting SAR practices allows Frontex to extend their operations into international waters, intercepting more migrant vessels pre-emptively categorized by the agency as 'at risk' and in 'need of rescue' (Pallister-Wilkins 2017, Andersson 2017). ${ }^{1}$ Moreover, SAR operations work to extend or disperse the EU's external borders even further into international waters - in line with the ongoing externalization of border management to North Africa - where migrants are deterred and/or pushed back into a worse fate in Libyan detention centers (Cuttitta 2014, Andersson 2017, Little and Vaughan-Williams 2017).

In contrast to Williams (2016) and Andersson (2017), Pallister-Wilkins (2017) does not see an inherent contradiction between SAR operations and more traditional border control, but rather see them as simply an expansion of traditional border control. Nevertheless, she contends that: 'Frontex and EU member state border police have realised that rescue works to justify and ... increase temporally and spatially the field of

\footnotetext{
${ }^{1}$ This blurring of the terms 'intercept' and 'rescue' is similar to the US Border Patrol's conflation of the terms 'apprehension'/'arrest' and 'rescue' (see Williams 2016).
} 
intervention allowing more people to be intercepted ... while reducing the numbers of deaths' (ibid.:93). More skeptical, Squire (2017) argues that humanitarian operations such as SAR work to shift the responsibility of border deaths onto the migrants themselves, as they 'should have known better' than to put themselves in vulnerable situations, making them seem 'irresponsible' in contrast to the 'responsible' savior. Aas and Gundhus (2014) further highlight Frontex's disregard for data gathering on migrant vulnerability and deaths at the border - focusing its intelligence rather on the 'vulnerability of borders', the 'risks' posed by migrants, and numbers saved (Frontex 2019).

Furthermore, NGOs involved in SAR operations in the Mediterranean have to comply with state instructions on where to disembark the rescued migrants in order for the state to fingerprint, register and/or detain them (Pallister-Wilkins 2017). If they fail to comply, they may be threatened with arrest on the grounds of human smuggling or refused to disembark, as news stories have reported the last few years (Cuttitta 2014, The Guardian 2018). NGOs operating on land also need to tread carefully, as they might face similar charges for bringing migrants to the hospital. This criminalization of nonstate humanitarianism in the EU-Mediterranean borderlands is similar to what has happened at the US-Mexico border (Williams 2016), and works to strengthen state sovereignty and territorial integrity (i.e. state security) at the expense of migrant's safety and wellbeing (i.e. human security) - along with reinforcing state-actors' monopoly on humanitarianism at the border (Cuttitta 2014). In addition to criminalization, NGOs carrying out humanitarianism at the border also sometimes 'internalize' the political rational of states, as Walters (2011) describes a Red Cross bulletin cautioning humanitarian actors to be 'careful' providing more than basic humanitarian assistance to migrants, so as not to create any 'pull factor that attracts more irregular migrants into making deadly voyages' (Red Cross 2006 in Walters 2011:156).

Now that we have considered some examples of 'humanitarian borderwork' in practice, an examination of how humanitarian these practices actually are is in order. According to Pallister-Wilkins (2017:86), 'humanitarian borderwork' - much like traditional humanitarianism - is concerned with 'saving lives, alleviating suffering and bearing witness'. Contrary to the role of borders, however, 'humanitarianism is...a humanist alternative to the international system made up of sovereign and exclusive territorial spaces' (ibid.:88). Moreover, in contrast to the universality principle of humanitarianism, discrimination or categorization is central to 'humanitarian borderwork'. As Pallister-Wilkins (2017:88) notes, 'the category 'refugee' carries with it a whole set of rights, responsibilities, politics, values and meanings' as opposed to the category 'migrant', which carries less weight. Hence, she claims, 'humanitarian borderwork enacts differentiated categories of life between those deemed worthy of help and those not' (ibid.:89, emphasis added). There is thus an inherent tension within 'humanitarian borderwork', which on the one hand strives to fulfill 'humanitarian principles' and relieve suffering at the border, and on the other 'reproduce exclusive 
categories of life and exclusive territorial spaces' (Pallister-Wilkins 2017:89). These selection- and inclusion/exclusion mechanisms operating in this 'politics of categorization' run counter to the humanitarian principles of humanity and universality, which hold that anyone is entitled to humanitarian assistance based on need alone without discrimination (NRC 2018).

Furthermore, Cuttitta (2014) points out the double standards in the EU's 'humanitarian' borderwork, only focusing on the humanitarian consequences of smuggling or trafficking, and not on those of the EU's migration policies and practices (similar to what Little and Vaughan-Williams 2017 argue regarding Australia's 'stop the boats' policy). Squire (2017:524) also points out the lack of identification and dignity in burial practices of migrants, where migrants are 'lumped together' in anonymous mass graves, separate from identified EU citizens' individual graves - further perpetuating 'exclusionary practices in death'. On a similar note, Pallister-Wilkins (2015b) highlights the inherent contradictions in 'humanitarian borderwork', noting how Frontex has to balance the need to ensure migrant welfare and at the same time restrict their mobility. Terming it the 'paradox of protection', she points out how the elements of care and control are applied in border control practices, with migrants both being a risk (to Schengen) and at risk at the border - hence in need of both care and control (see also Aas and Gundhus 2014, Andersson 2017). Humanitarianism's traditional concern with 'care for distant Others' all of a sudden becomes 'keeping Others distant' (PallisterWilkins 2018), as these 'Others' are showing up on Europe's doorstep. If conceived of in Foucauldian terms of power, one could argue that this 'care and control duality' (Pallister-Wilkins 2015b:54) in humanitarian border practices is an extension of a form of governmentality or humanitarian governance exercised by the EU over the movement of populations through measures of care and control, monitoring and surveillance.

Situating her analysis into 'wider debates about the double-sided nature of a humanitarian governance concerned with care and control', Pallister-Wilkins (2015b:54/59) cautions that one should not mistake humanitarianism for 'an act of kindness', but rather, as an act 'based on hierarchies of power utilized for the governance of populations' (see also Ticktin 2014, De Lauri 2016). As she contends, moral sentiments have become a 'powerful force in contemporary political life, feeding hegemonic discourse and legitimizing practices' (Pallister-Wilkins 2015b:59). Thus, by invoking this humanitarian discourse Frontex (similarly to the US Border Patrol) aims to fend off criticism and be seen as a legitimate player whose absence would result in more deaths at sea and unauthorized entries to the EU (Campesi 2014). Importantly, Little and Vaughan-Williams (2017:542) argue that this humanitarian discourse is misleading as it purports to be the solution to violent borders, diverting attention away from the possibility that these policies actually perpetuate the very forms of suffering they claim to alleviate. This gap between rhetoric and practice is also hard to tackle, because as Pallister-Wilkins (2015a:n.p.) puts it: 'who, after all, is against saving lives?'. 
How then, does Frontex's 'humanitarian borderwork' fare compared to the traditional principles of humanitarianism? Returning to the definition of the concept in the literature, humanitarianism should not have other agendas, and it should be considered by the targeted as 'helpful' (Apthorpe 2014). Whether this is the case for migrants being 'rescued' (i.e. apprehended/arrested) in the words of the US Border Patrol on the US-Mexico border, or with migrant vessels being 'saved' (i.e. intercepted and pushed back or detained and possibly deported) by Frontex in the Mediterranean is questionable. Moreover, Frontex, being an EU agency, by design does not meet the principle of independence, which calls for humanitarian actors to be apolitical. Whereas the NRC (2016) claims to 'remain independent from political, economic, military or other non-humanitarian objectives' as one of its fundamental principles, Frontex's (2018b:n.p.) mission is to 'together with the Member States...ensure safe and wellfunctioning external borders providing security'. As mentioned, Frontex also seemingly fails to meet the humanity principle, that all lives are equal, and to 'do no harm' - as attested by the discriminatory 'politics of categorization' (Pallister-Wilkins 2017) and critique of 'inhumane treatment' by civil society actors and the European Court of Human Rights (Leonard 2009, Aas and Gundhus 2014).

It is also debatable whether Frontex, being a non-elected, supranational agency, meets the accountability principle of humanitarianism. As Dünnwald (2011) observes, no migrants have taken their case against Frontex so far, partially due to the difficulty of ascertaining who is to blame and at which court such action should be taken. PallisterWilkins (2011:n.p.) also notes that 'there is a fundamental problem with accountability in EU migration-management practices that comes down to ascertaining who in fact is ultimately responsible' (see also Eriksen 2011). The priorities are unmistakable: while the MSF and Red Cross cater to their recipients, Frontex serves the EU member states. Frontex has also been criticized for 'acting on the fringes of international law' and in a 'legal' void by claiming it cannot be held accountable for human rights abuses when acting as a mere 'facilitator' on member states grounds (Pallister-Wilkins 2011, Aas and Gundhus 2014). However, what much of this 'confusion' reveals, according to PallisterWilkins (2015a:58), 'is the unreconciled relationship between member states' sovereign responsibility for border control on behalf of Schengen, and attempts at ... facilitation, and coordination in border control at the European level, institutionally represented and materially operated by Frontex'. Frontex has become a scapegoat for the EU's violent border regime, whether this criticism is unfounded or not (Perkowski 2018).

Whereas Frontex then does not seem to meet the traditional principles of humanitarianism, it seems to fit perfectly within the 'new humanitarianism' that emerged in the post-Cold War context, as sketched out by Nascimento (2015). In this new context, non-state and state actors increasingly operate side-by-side, and militarization and securitization go hand-in-hand with humanitarian pursuits - as exemplified by the 'humanitarian interventions' in Iraq, Afghanistan and Libya (De Lauri 2016, 2018). In this new reality, the US army or NATO are just as likely to be humanitarian actors as 
the MSF or the Red Cross, whether they are dropping food from the air or 'liberating' civilians from oppressive regimes (ibid.). As Pallister-Wilkins (2015b:59) contends '...these [traditional humanitarian] principles are undermined, ignored, and transformed as humanitarian motivations are deployed by militaries, police forces, and government agencies in various situations for the governance of "problematic peoples" such as insurgent populations, colonized subjects and ... migrants'.

This more frequent deployment of the concept of humanitarianism has also led to confusion as to what it actually entails, and points to a tension within it, as it is based on 'universal claims that can be both oppressive and liberating' (Palliser-Wilkins 2015b:59, emphasis added). In line with 'minimalist biopolitics', Pallister-Wilkins (2015a) criticizes humanitarianism for not being concerned with what happens to migrants after they are rescued, and argues that whether migrants are rescued by Frontex or a humanitarian NGO does not matter as they all end up in the same place in the end: detention centers. Anthropologists writing about humanitarian governance have also noted the 'increasingly symbiotic relationship between humanitarian government and policing', arguing that "there is no care without control"' (Agier 2011:4-5 in PallisterWilkins 2015b:59), that humanitarianism and policing are actually two sides of the same coin (Ticktin 2005 in Pallister-Wilkins 2015b:59), and that 'humanitarianism and securitization, compassion and repression, hospitality and hostility are not in...contradiction with each other', but rather 'inextricably intertwined' (Fassin 2012 in Little and Vaughan-Williams 2017:543). This ambivalence 'permeates contemporary discourses and practices of compassionate borderwork' (Little and Vaughan-Williams 2017:544) and allow 'brutal measures...[to] accompany actions in the name of care and rescue - measures that ultimately work to reinforce an oppressive order (Ticktin 2011 in Little and Vaughan-Williams 2017:547).

\section{Humanitarian Borders as Spaces of Exception?}

What are some of the consequences of 'humanitarian borderwork'? As discussed, the practices of 'humanitarian borderwork' produces a certain form of border, the so-called 'humanitarian border' (Walters 2011, Pallister-Wilkins 2017). Since at this site the 'politics of categorization' are key in determining who should be allowed to cross the border and who should not - a hierarchy of vulnerabilities or categories of life is created, producing what Agamben (1998) calls 'homo sacer', limited life stripped of all rights and reduced to mere biological life. As Squire (2017:514) argues, referring to the deadly consequences of being left to the forces of nature at desert- or sea borders, this 'biophysical violence' and its associated deaths have become 'an established feature of contemporary border politics'. Hence, in many instances, as Pallister-Wilkins (2017:97) contends, 'the presence of the border is what generates vulnerability and suffering and the subsequent need for humanitarian assistance' in the first place. 
Moreover, state actors often involve humanitarian NGOs in their 'politics of categorization', as Pallister-Wilkins (2017) illustrates happened at the GreekMacedonian border, where the UNHCR - an agency with the sole purpose of protecting refugees - assisted the Greek police in differentiating between migrants, determining who was a 'legitimate' refugee or not. This 'politics of categorization' classifies migrants according to gender, age, nationality, and vulnerability (ibid.) - often determined by bodily markers, and not the migrants' own testimony - which goes against the universality principle of humanitarianism, where everyone is entitled to help regardless of ascribed categories. Furthermore, state actors increasingly patrol refugee camps, and the so-called 'reception centers' in the EU-Mediterranean borderlands (which in Italy have proven to be ridden with corruption) have increasingly turned into longer-term, sub-standard detention centers through the EU's recent hotspot approach, depriving migrants of mobility (DeBono, forthcoming; Orsini, forthcoming).

As Schmitt (1985) and Agamben (2005) argue, 'crises' produce exceptionality, or a 'state of exception' - a limited temporal space where 'normality' and 'ordinary practices' yield to 'the exception' and 'extraordinary measures' called for and legitimized by said 'crisis'. The 'humanitarian border' can thus be understood as a 'space of exception', produced by the securitization- and 'crisification' of migration (which leads to a securitization of borders as well). This situation allows Frontex to operate with impunity in a prolonged state of exception, excluding certain individuals and groups from basic rights and legal protections - producing what Agamben (2005:3) calls 'legally unnamable and unclassifiable beings'. As Pallister-Wilkins (2015a:n.p.) underlines, the problem with 'events framed as emergencies' is that they 'demand a response that moves us beyond politics and into the realm of exception', where 'practices that would at another time seem excessive...suddenly became normalised or acceptable when the stakes are so high'. She argues that the 'migration crisis' was not 'exceptional' and should not have been unforeseen to EU policymakers, as it was the result of longstanding policies closing down safe and legal routes into the EU. Conceiving of it as a 'crisis' is thus misleading as it 'conceals a restrictive European border control system at the heart of these deaths' (Pallister-Wilkins 2015a:n.p.).

This 'crisis labelling' (see Jeandesboz and Pallister-Wilkins 2016) is particularly troublesome if it has become what Agamben (1998) terms 'a state of willed exception', where the state of exception increasingly has become the rule (as he believes is the case in Western democracies) and instruments of exceptional measures depicted as temporary crisis arrangements have transformed into permanent techniques of governing. In this sense, the 'humanitarian border', far from being humanitarian, can be conceived of as a 'zone of humanitarian crisis', where the use of force is authorized to 'protect people'. As Little and Vaughan-Williams (2017:535) argue, this 'compassionate borderwork' is 'symptomatic of a broader governmental logics that attempt to simultaneously enhance and save lives biopolitically'. Conspicuously, this 'humanitarian emergency' logic or 
rhetoric has enabled an incremental expansion of Frontex's mandate, budget and resources over the years (Campesi 2014).

In this way, the EU's borderzones are transformed into, in Schmitt (1985) and Agamben's (1998) words, an 'ambiguous zone', 'a no-mans land', a 'zone of indifference' or 'anomie' - a space where law recedes, but that is simultaneously penetrated by an extension of government power, reducing political beings (i.e. migrants) to 'life devoid of value', which may be sacrificed for the greater good of order and stability within the state. This could be said to be a form of modern biopolitics: the power to decide who is to be included or excluded in the political body, and what constitutes 'bare life' - life stripped of any legal and political rights (Agamben 1998), which is subsequently 'left to die' at the hands of the biophysical violence of the border (Squire 2017). As Squire (2017:516) contends, these 'dynamics of abandonment', biopolitical techniques of death, or practices of desertion have become a mode of governing that disregards lives 'not worth living'.

This is the form of life that we find today in the EU's borderzones, on the many vessels in the Mediterranean intercepted by Frontex, or in detention centers. As Agamben (1998:81, emphasis added) paraphrases Arendt's paradox: '...the very figure who should have embodied the rights of man par excellence - the refugee - signals instead the concept's radical crisis'. The question we should be asking then - as Agamben (1998:110) did about the concentration camps of the $20^{\text {th }}$ century (as the 'ideal form' of a space of exception) - is how the "...juridical procedures and deployments of power [came about] by which human beings could be so deprived of their rights...that no act committed against them could any longer appear as a crime"?

\section{CONCLUSION}

This paper has problematized the concept of 'humanitarian borderwork', which emerged in the critical border studies literature in the US post-9/11 context (Williams 2016) and in Europe during the migration crisis (Cuttitta 2014, Pallister-Wilkins 2015b) as an attempt to explain state actors' increasing emphasis on humanitarian elements in their border control practices. Further, the paper examined Frontex's humanitarian discourse and practices - based on a theoretical discussion and qualitative reading of existing literature - arguing that this recent emphasis on humanitarianism in border control came about both as a response to criticism from civil society actors for lack thereof; and as a result of mounting deaths in the Mediterranean due to the closing down of safe and legal routes into the EU (Campesi 2014, Perkowski 2018). Shedding light on the genealogy of the 'humanitarian borderwork' discourse, the paper also illustrated how a process of discourse co-optation took place, whereby Frontex included the humanitarian elements of its critics, arguing that the agency now 'saves lives' rather than 'kills'. By deploying a humanitarian discourse in framing its operations, Frontex '...casts itself as a moral actor and protector of human life, securing itself against criticism and 
strengthening its position as an actor in European border policing' (Pallister-Wilkins 2015b:65) - obscuring the political failures causing the 'crisis' in the first place.

Further, illustrating how 'humanitarian borderwork' is composed of two traditionally opposing elements, the paper examined the form of humanitarianism that is implied in the concept, arguing that Frontex's 'humanitarian borderwork' fails to meet the standards of the traditional understanding of humanitarianism, i.e. the principles of humanity, neutrality, impartiality, independence, accountability, universality and 'do no harm' (MSF 2018, ICRC 2018, NRC 2018, Save the Children 2018). As humanitarianism as a concept has evolved, however, these principles have weakened over time, and state actors - including the police, military and border guards - have entered the field of humanitarianism (Nascimento 2015; De Lauri 2016, 2018). In this messy field of 'new humanitarianism', the world is turned upside down, with former taken-for-granted dichotomies such as migrant safety/border security and humanitarianism/militarism becoming mutually attainable goals, and distinctions between terms like arrested/rescued (Williams 2016), intercepted/saved (PallisterWilkins 2015b), reception/detention, humanitarian action/trafficking (Walters 2011) and repatriation/deportation becoming blurred. As Williams (2016) and PallisterWilkins (2015b) quote border guards saying, due to the increasingly violent borders, migrants are now 'happy' to see them.

Perhaps it is more correct to refer to the humanitarian discourse and practices employed by Frontex as a new form of humanitarian governance exercised by border control agencies - rather than 'humanitarian borderwork' - as it brings out the governmentality aspect in Frontex's practices. In the same vein, the term 'humanitarian border' might be misleading, as it is actually anything but humanitarian. Moreover, the issue of humanitarianism in the Mediterranean remains relevant, as migrant mortality rates have increased after the 'migration crisis', with 1 in 18 dying crossing the Central Mediterranean route in the spring of 2018, and 1 in 7 in June alone - as a result of the criminalization of non-state actors engaged in humanitarianism at sea (UNHCR 2018, see also Cuttitta 2014). This has happened despite Frontex's budget increases and SAR operations. It seems as Frontex is increasingly struggling to wear two hats at the same time, being responsible both for the 'care' and 'control' of migrants. The issue lies in trusting the same agency with two contradictory tasks that are perhaps best ensured separately. The issue is not that Frontex 'saves lives', but rather as Williams (2015) contend, that 'humanitarian borderwork' has proven to be a 'double-edged sword', where SAR operations do save lives, 'but only so that they [migrants] might be more effectively apprehended, detained, and deported' - with migrants getting caught up in a never-ending 'apprehension-detention-deportation cycle' (Williams 2015:n.p.). More reflection over the question of 'who can act in the name of humanitarianism and how' (Walters 2011) - and with what consequences - hence remains potent for future research, not only within anthropology or border studies but the wider social sciences too. 


\section{REFERENCES}

Aas, Katja Franko and Helene O. I. Gundhus (2014). 'Policing Humanitarian Borderlands: Frontex, HumanRights and the Precariousness of Life'. British Journal of Criminology, 55(1).

Agamben, Giorgio (1998). Homo Sacer: Sovereign Power and Bare Life. Stanford University Press.

Agamben, Giorgio (2005). State of Exception (Vol. 2). University of Chicago Press.

Agier, Michel (2011). Managing the Undesirables: Refugee Camps and Humanitarian Government. TransDavid Fernbach. Cambridge: Polity Press.

Amoore, Louise (2006). 'Biometric Borders: Governing Mobilities in the War on Terror'. Political Geography, 25(3).

Andersson, Ruben (2017). 'Rescued and Caught: The Humanitarian-Security Nexus at Europe's Frontiers', in de Genova (ed.) The Borders of 'Europe': Autonomy of Migration, Tactics of Bordering. Durham. Duke University Press.

Apthorpe, Raymond (2014). 'Anthropology and Humanitarianisms Across Borders: A Growing Field of Study'. Journal of the Royal Anthropological Institute, 20.

Barnett, Michael (2011). Empire of Humanity: A History of Humanitarianism. London: Cornell UniversityPress.

Billaud, Julie and Antonio De Lauri (2016). 'Humanitarian Theatre: Normality and the Carnivalesque inAfghanistan', in De Lauri (ed.) The Politics of Humanitarianism: Power, Ideology and Aid.London: I. B. Tauris.

Campesi, Giuseppe (2014). 'Frontex, the Euro-Mediterranean Border and the Paradoxes of HumanitarianRhetoric'. South East European Journal of Political Science, 2(3).

Cuttitta, Paolo (2014). 'From the Cap Anamur to Mare Nostrum. Humanitarianism and Migration Controls at theEU's Maritime Borders'. In Matera and Taylor (eds.): The Common European Asylum System and HumanRights: Enhancing Protection in Times of Emergencies. Den Haag: Asser Institute.

De Lauri, Antonio (2016). 'Introduction'. In De Lauri (ed.): The Politics of Humanitarianism: Power, Ideology and Aid. London: I. B. Tauris.

De Lauri, Antonio (2018). 'Humanitarian Militarism and the Production of Humanity'. Social Anthropology, 0. 
De Torrente, Nicolas (2004). 'Humanitarian Action under Attack: Reflections on the Iraq War'. Harvard HumanRights Journal, 17.

Donini, Antonio (2010). 'Humanitarianism in the 21 ${ }^{\text {st }}$ Century'. Humanitaire, (25).

Dünnwald, Stephan (2011). 'On Migration and Security: Europe Managing Migration from Sub-Saharan Africa'. Cadernos de Estudos Africanos, 22.

Ekelund, Helena (2014). ‘The Establishment of FRONTEX: A New Institutionalist Approach'. Journal of European Integration, 36(2).

Eriksen, Erik O. (2011). 'Governance between Expertise and Democracy: The Case of European Security'.Journal of European Public Policy, 18(8).

Fassin, Didier (2007). 'Humanitarianism: A Nongovernmental Government'. In Michel Feher (ed.):Nongovernmental Politics. New York: Zone Books.

Fassin, Didier (2012) Humanitarian Reason: A Moral History of the Present. Trans Rachel Gomme.Berkeley, CA: University of California Press.

Feldman, Ilana and Miriam Ticktin (2010). In the Name of Humanity: The Government of Threat and Care(eds.). Durham, NC: Duke University Press.

Fine, Shoshana (2018). 'Back to Frontex: Europe's Misguided Migration Policy’, September 27. European Council on Foreign Relations (ECFR). Accessible from:https://www.ecfr.eu/article/commentary back to frontex europes misguided migration policy [Accessed 14/12/18].

Gilman, Nils (2012). 'Preface: Militarism and Humanitarianism'. Humanity: An International Journal of Human Rights, Humanitarianism, and Development, 3.

Guilhot, Nicolas (2012). 'The Anthropologist as Witness: Humanitarianism between Ethnography and Critique'. Humanity: An International Journal of Human Rights, Humanitarianism, and Development, 3(1).

Jeandesboz, Julien and Polly Pallister-Wilkins (2014). 'Crisis, Enforcement and Control at the EU Borders'.In Anna Lindley (ed.): Crisis and Migration: Critical Perspectives. London: Routledge.

Jeandesboz, Julien and Polly Pallister-Wilkins (2016). 'Crisis, Routine, Consolidation: The Politics of the Mediterranean Migration Crisis'. Mediterranean Politics, 21(2). 
Jensen, Leif Christian (2016). International Relations in the Arctic: Norway and the Struggle for Power in the New North. London: I.B. Tauris.

Jørgensen, Marianne W., and Louise J. Phillips (2002). Discourse Analysis as Theory and Method. London:Sage.

Kane, Linda (2004). 'Border Safety Initiative: A Multi-faceted Approach to Enhancing Border Safety'. Customs and Border Protection Today.

Leonard, Sarah (2009). 'The Creation of FRONTEX and the Politics of Institutionalisation in the EU External Borders Policy'. Journal of Contemporary European Research, 5(3).

Little, Adrian and Nick Vaughan-Williams (2017). 'Stopping Boats, Saving Lives, Securing Subjects:Humanitarian Borders in Europe and Australia'. European Journal of International Relations, 23(3).

Nascimento, Daniela (2015). 'One Step Forward, Two Steps Back? Humanitarian Challenges and Dilemmas in Crisis Settings'. The Journal of Humanitarian Assistance, February 18.

Pallister-Wilkins, Polly (2011). 'Searching for Accountability in EU Migration-Management Practices', October 19. OpenDemocracy. Accessible from: https://www.opendemocracy.net/polly-pallisterwilkins/searchingfor-accountability-in-eu-migration-management-practices [Accessed 6/2/19].

Pallister-Wilkins, Polly (2015a). 'The Humanitarian Policing of 'Our Sea”, April 20. Border Criminologies.Accessible from: https://www.law.ox.ac.uk/research-subject-groups/centrecriminology/centrebordercriminologies/blog/2015/04/humanitarian [Accessed 11/12/18].

Pallister-Wilkins, Polly (2015b). 'The Humanitarian Politics of European Border Policing: Frontex and Border Police in Evros'. International Political Sociology, 9(1).

Pallister-Wilkins, Polly (2017). 'Humanitarian Borderwork'. In Günay C. and Witjes N. (eds.): Border Politics: Defining Spaces of Governance and Forms of Transgressions. Springer, Cham.

Pallister-Wilkins, Polly (2018). 'Hotspots and the Geographies of Humanitarianism'. Environment and Planning D: Society and Space, $0(0)$.

Perkowski, N ina (2018). 'Frontex and the Convergence of Humanitarianism, Human Rights andSecurity'. Security Dialogue, 49(6).

Redfield, Peter (2005). 'Doctors, Borders, and Life in Crisis'. Cultural Anthropology, 20(3). 
Redfield, Peter and Erica Bornstein (2011). 'An Introduction to the Anthropology of Humanitarianism'. In Redfield and Bornstein (eds.): Forces of Compassion: Humanitarianism Between Ethics and Politics. Santa Fe, N.M.: School for Advanced Research Press.

Sandvik, Kristin Bergtora (2017). 'Now is the Time to Deliver: Looking for Humanitarian Innovation's Theoryof Change'. Journal of International Humanitarian Action, 2(8).

Schmitt, Carl (1985). Political Theology: Four Chapters on the Concept of Sovereignty. The MIT Press.

Skinner, Rob and Alan Lester (2012). 'Humanitarianism and Empire: New Research Agendas'. The Journal of Imperial and Commonwealth History, 40(5).

Squire, Vicki (2017). 'Governing Migration through Death in Europe and the US: Identification, Burial and the Crisis of Modern Humanism'. European Journal of International Relations, 23(3).

Ticktin, Miriam (2005). 'Policing and Humanitarianism in France: Immigration and the Turn to Law as State of Exception'. Interventions, 7(3).

Ticktin Miriam (2011). Casualties of Care: Immigration and the Politics of Humanitarianism in France.Berkeley, CA, and London: University of California Press.

Ticktin, Miriam (2014). 'Transnational Humanitarianism'. Annual Review of Anthropology, 43.

Trauner, Florian (2016). 'Asylum Policy: the EU's 'Crises' and the Looming Policy Regime Failure'. Journal of European Integration, 38(3).

Vauchez, Antoine (2016). Democratizing Europe. New York: Palgrave Macmillan.

Walters, William (2011). 'Foucault and Frontiers: Notes on the Birth of the Humanitarian border'. In Bröckling, U., Krasmann, U. and T. Lemke (eds.): Governmentality: Current Issues and Future Challenges. New York: Routledge.

Williams, Jill M. (2015). 'The Case Against the "Humanitarian Border”', December 22. North American Congress on Latin America (NACLA). Accessible from: https://nacla.org/news/2015/12/21/case againsthumanitarian-border [Accessed 14/12/18].

Williams, Jill M. (2016). 'The Safety/Security Nexus and the Humanitarianisation of Border Enforcement'. The Geographical Journal, 182. 
Wynter, Alex. (2006). 'Deadly Passage'. Magazine of the International Red Cross and Red Crescent Movement.

European Council (2016). 'European Border and Coast Guard: Final Approval', September 14. Press release. Accessible from: https://www.consilium.europa.eu/en/press/press-releases/2016/09/14/europeanbordercoast-guard/ [Accessed 6/2/19].

Frontex (2011). 'Frontex's Reaction to HRW Report'. News release, September 21. Accessible from: https://frontex.europa.eu/media-centre/news-release/frontex-s-reaction-to-hrw-report-uw7Qqq[Accessed 30/7/19].

Frontex (2018a). 'Legal Basis'. Accessible from: https://frontex.europa.eu/about-frontex/legal-basis/ [Accessed 21/11/18].

Frontex (2018b). 'Vision, Mission and Values'. Accessible from: https://frontex.europa.eu/about-frontex/vision mission-values/ [Accessed 5/12/18].

Frontex (2018c). 'Fundamental Rights at Frontex'. Accessible from:

https://frontex.europa.eu/fundamentalrights/fundamental-rights-at-frontex/ [Accessed 6/12/18].

Frontex (2018d). ‘Complaint Mechanism'. Accessible from:

https://frontex.europa.eu/fundamentalrights/complaint-mechanism/ [Accessed 6/12/18].

Frontex (2019). ‘FAQ: Frontex Operations'. Accessible from: https://frontex.europa.eu/faq/frontexoperations/

[Accessed 12/2/19].

The Guardian (2018). 'Italian Minister Declares Victory as Spain Accepts Rescue Boat', June 11. Kirchgaessner, S., Tondo, L. and S. Jones. Accessible from: https://www.theguardian.com/world/2018/jun/11/un-calls-formigrant-ship-to-be-allowed-to-dock-in italian-port [Accessed 5/12/18].

Human Rights Watch (HRW) (2011). 'The EU's Dirty Hands. Frontex Involvement in Ill-Treatment of Migrant Detainees in Greece'. Accessible from: https://www.hrw.org/sites/default/files/reports/greece0911webwcover 0.pdf [Accessed 6/2/19].

International Committee of the Red Cross (ICRC) (2018). 'Fundamental Principles'. Accessible from: https://www.icrc.org/en/fundamental-principles [Accessed 3/12/18].

IOM (2018a). 'Missing Migrants Project'. Accessiblefrom: http://missingmigrants.iom.int/region/mediterranean [Accessed 21/11/18]. 
IOM (2018b). 'Flow Monitoring Europe'. Accessible from:

http://migration.iom.int/europe?type=arrivals [Accessed 21/11/18].

Médecines Sans Frontières (MSF) (2018). 'An International, Independent Medical Humanitarian Organisation'. Accessible from: https://www.msf.org/who-we-are [Accessed 4/12/18].

The Norwegian Refugee Council (NRC) (2016). 'Humanitarian Principles', January 21. Accessible from: https:/www.nrc.no/what-we-do/speaking-up-for-rights/humanitarian-access/ [Accessed 3/12/18].

Save the Children (2018). 'Our Vision, Mission and Values'. Accessible from:

https://www.savethechildren.net/about-us/our-vision-mission-and-values [Accessed 3/12/18].

UNHCR (2016). 'Mediterranean Death Toll Soars, 2016 is Deadliest Year Yet', October 25. Accessible from: https://www.unhcr.org/news/latest/2016/10/580f3e684/\%09mediterranean-death-toll soars2016\%09deadliest-year.html [Accessed 21/11/18].

UNHCR (2018). 'As Mediterranean Sea Arrivals Decline and Death Rates Rise, UNHCR Calls for Strengthening of Search and Rescue', July 6. Accessible from:

https://www.unhcr.org/news/briefing/2018/7/5b3f270a4/mediterranean-sea-arrivals-decline-death-rates rise-unhcr-calls-strengthening.html [Accessed 14/12/18]. 